Nevşehir Bilim ve Teknoloji Dergisi Cilt 6(ICAFOF 2017 Özel Sayı) 178-191 2017

DOI: 10.17100/nevbiltek.345499

URL: http://dx.doi.org/10.17100/nevbiltek.345499

\title{
Gıda Rejimi Perspektifinden Türkiye’de Şeker Kanununun Değerlendirilmesi ve Bir Regülasyon Kurumu Olarak Şeker Kurulu’nun Düzenleyici Rolü
}

\author{
Gonca BIYIK * , Selin ERTÜRK ATABEY \\ Gazi Üniversitesi, İktisadi ve İdari Bilimler Fakültesi, Maliye Bölümü, Ankara
}

Öz

Çalışmada tarımsal üretim açısından önemli bir paya sahip şeker üretiminin düzenlenmesine yönelik olarak Türkiye'de hazırlanan ve günümüzde uygulanmakta olan Şeker Kanunu gıda rejimi perspektifinden ele alınmış ve bir regülasyon kurumu olan Şeker Kurulu'nun düzenleyici rolü incelenmiştir. Gıda rejiminin birinci ve ikinci safhaları literatürde netlik kazanmış iken üçüncü safhanın varlığı ve gelişimi konusunda henüz uzlaşıya varılmış değildir. Her ne kadar gıda rejiminin üçüncü safhası konusunda netlik bulunmasa da birinci ve ikinci safhalar göz önünde bulundurularak 1990'lardan itibaren hızlanan küreselleşme olgusu açısından Şeker Kanunu incelenmiştir. Ayrıca Şeker Kurulu'nun bir regülasyon kurumu olarak uyguladığı kotalar perspektifinden de Şeker Kanunu'nun incelenmesi ihtiyacı doğurmuştur. Devletler, maliye politikalarının yanı sıra kanuni ve kurumsal önlemlerle de piyasaları düzenleyebilir bu bağlamda da Şeker Kurulu bir regülasyon kurumu olarak çalışmada incelenmiş ve şeker piyasası üzerindeki düzenleyici rolü tespit edilmeye çalışılmıştır. Sonuç olarak mevcut uygulamalarda şeker üretimi için şeker pancarının ekilen dekar başı azaltılmakta ve yurtdışından nişasta esaslı şeker üretimi için gerekli tohum ithalatı yapılmaktadır. Bu da fiyat açısından ithalatı cazip kılar iken ihracatı azaltmakta ve Türkiye'yi şeker üretimi açısından ihracatçı ülke konumundan çıkarıp ithalata bağımlı hale getirmektedir.

Anahtar Kelimeler: Gıda Rejimi, Regülasyon, Kamu Politikası, Şeker Kanunu, Şeker Kurulu.

\section{Evaluation of Sugar Law from the Food Regime Perspective and the Regulatory Role of the Sugar Board as a Regulation Agency}

\begin{abstract}
In order to regulate the production of sugar, which has a significant share in terms of agricultural production in the study, The Sugar Law prepared in Turkey and currently implemented has been taken from the perspective of food regime and examined the regulatory role of the Sugar Board as a regulatory agency. While the first and second stages of the food regime are clear in the literature, the existence and development of the third stage has not yet been reached consensus. Although there is no clarity about the third stage of the food regime considering the first and second stages, the Sugar Law was examined in terms of the globalization phenomenon accelerating from the 1990s. In addition, from the perspective of the quota which the Sugar Board implements as a regulatory institution Sugar Law has created the need to be examined. States can regulate markets with fiscal and institutional measures as well as fiscal policies in this context, the Sugar Board has been studied as a regulatory institution and the regulatory role on the sugar market. As a result, in current applications sugar beet per capita is reduced for sugar production and seed import is made from abroad for starch-based sugar production. While this makes imports attractive in terms of price, it reduces exports and makes Turkey an exporting country dependent on imports in terms of sugar production.
\end{abstract}

Keywords: Food Regime, Regulation, Public Policy, Sugar Law, The Sugar Boar

*e-mail: goncabiyik@gazi.edu.tr 


\section{Nevşehir Bilim ve Teknoloji Dergisi Cilt 6(ICAFOF 2017 Özel Sayı) 178-191 2017}

\section{Giriş}

İnsanların ve toplumların daha doğrusu nesillerin devamının sağlanabilmesi için temel fizyolojik ihtiyaçların başında gelen beslenme ve gıda temini yüzyıllardır pek çok unsuru etkilemiştir. Öncelikle yerleşim yerinin tercih edilmesinde etkili olan su kaynaklarına yakınlık ve gida temini olabilecek alanların varlığı beraberinde ticarete konu olacak ürünlerin kapsamını ve ticaret ilişkilerini etkilemiştir. Ayrıca su kaynaklarının ve gıda temini sağlayan alanların sınırına yaklaşılması veya tükenmesi sonucunda göç hareketleri başlayarak yeni yerlerin keşfine de olanak sağlanmıştır. Dolayısıyla beslenme ihtiyacı ve gıda temini günümüze gelinceye değin pek çok yerleşim yerinin kurulmasında, devletlerin yapılanmasında, ticari ilişkilerde, ulusal ve uluslararası politikaların şekillenmesinde ve devletler arasındaki güç ilişkilerinde önemli bir unsur olmuştur. Günümüzde de bu önemin hâlâ geçerli olduğunu söylemek hiç kuşkusuz mümkündür. Gıda ihtiyacı ve temini her biri farklı özelliklere sahip olan çeşitli dönemlerde tarihsel olarak incelenebilmektedir. Bu noktada gıda rejimi kavramı ortaya çıkmaktadır.

Gıda rejimlerinde meydana gelen dönüşümlerin nedenleri arasında yükselen ekonomilerde meydana gelen gıda talebindeki artışlar, ulusal gıda ihtiyacına yönelik tarım politikaları yerine ihracat temelli tarım politikalarının benimsenmesi, dünya ölçeğinde bio-dizel talebindeki artış, küresel ısınma sonucunda ortaya çıkan ani mevsimsel değişiklikler, sel, kuraklık ve benzeri doğal afetler, kötü hasatlar, enerji fiyatlarındaki artışlar, döviz kurundaki dalgalanmalar, ülkelerin gıda güvenliklerini sağlamak amaçlı uyguladıkları ihracat kotaları gibi nedenler yer almaktadır.

Toplum içinde yaşamanın zorunlu sonucu olarak ortak ihtiyaçların devlet tarafından karşılanması gereği ortaya çıkmaktadır. Bu ihtiyaçların devlet tarafından karşılanması için de finansmana gerek duyulmaktadır. Devlet bu ikili dengeyi düzgün ve doğru kurabilmek için maliye politikası araçlarını kullanmaktadır. Maliye politikası araçlarının yanı sıra aynı zamanda devletler düzenleyici ve denetleyici rollerini gerçekleştirmek için regülasyona da başvurmaktadırlar. Bu doğrultuda çalışmada gıda rejimi perspektifinden Türkiye'de Şeker Kanunu değerlendirilecek ve bir regülasyon kurumu olan Şeker Kurulunun düzenleyici rolü incelenecektir.

\section{Gida Rejimi ve Gıda Rejiminin Evreleri}

Gıda ihtiyacı ve temini her biri farklı özelliklere sahip olan çeşitli dönemlerde tarihsel olarak incelenebilmektedir. Bu noktada gıda rejimi kavramı ortaya çıkmaktadır. Gıdanın bir rejiminin olmasında değişen konjonktürel etkilerin payı vardır. Ayrıca gıda ile ilgili insanların beklentileri ve değişen tercihleri, ticaret ilişkileri ve gıdanın bir politika unsuru olması da gıda rejiminin ortaya çıkmasında etkilidir.

Gıda rejimi kavramının kullanılmasındaki amaç kapsamlı bir politik ekonomi ve gıdanın politik ekolojisinin çok önemli olması ve sadece gıda krizlerinin boyutlarına basitçe anlamaya değil aynı zamanda dünya gıda sistemini ve onun krizlerini jeopolitik ve ekolojik durumlarının geniş bir tarihsel anlayışı içinde konumlandırmaya olanak tanımasıdır [1].

Gıda rejimi kavramı içinde gıda ve rejimin birlikte anılmasında $1925^{\prime}$ te dünya ekonomisinin genel çöküşünün öncesinde tahıl fiyatlarının hızla düşmesi, 1929'dan sonra gıda ve tarımın ağırlıklı olarak iki ülke arasındaki ulusal ilişkileri yeniden sağlamak için hükümet politikalarının tekrar açık odak noktası olması, 1970'lerin başında tarım ve gıdayı tamamen değiştiren üretim, taşımacılık ve sanayi 
ürünlerinin satışının yeni ilişkilerinin yapısının bir kez daha kamu politikasının arka planına düşmesi gibi konjonktürel etkiler rol oynamıştır.

Metodolojik açıdan gıda rejimi, birikim, üretim süreci ve emek güçlerinin yeniden üretiminin temeli olarak zaman ve mekan boyunca tarımsal ilişkilerin sermaye yapılanmasını anlatmaktadır [2]. Gıda rejiminin üç farklı dönemi bulunmaktadır. Bu dönemler ve özellikleri Tablo-1'de incelenmiştir.

Tablo1. Gıda Rejimlerinin Dönemleri ve Özellikleri

\begin{tabular}{|c|c|c|c|}
\hline & Birinci Gıda Rejimi: & İkinci Gıda Rejimi: & Ücüncü Gıda Rejimi: \\
\hline & Göçmen & Merkantilist & Kurumsal \\
\hline & - & - & - \\
\hline & Koloniyel Gıda Rejimi & Sınai Gıda Rejimi & Çevresel Gıda Rejimi \\
\hline Dönem & $1870-1914$ & $1947-1972$ & $1980-\ldots$ \\
\hline Egemen Ülke & İngiltere & $\mathrm{ABD}$ & $\begin{array}{l}\text { Uluslararası Birlikler, } \\
\text { Uluslararası Kuruluşlar, } \\
\text { Uluslararası Şirketler ve } \\
\text { Uluslararası Piyasalar }\end{array}$ \\
\hline $\begin{array}{l}\text { Hareket } \\
\text { Noktası }\end{array}$ & İthalat Korumasını Kaldırmak & $\begin{array}{c}\text { Tarımda Serbest Ticareti } \\
\text { Kurmak }\end{array}$ & $\begin{array}{l}\text { Tarımsal Üretimin } \\
\text { Finansallaşması }\end{array}$ \\
\hline Yatırımlar & Demiryolu ve Gemicilik & Mali Destek & Dolaylı Portföy Yatırımları \\
\hline Döneme Etkisi & Avrupa'dan Diğer Ülkelere Göç & Tarımın Modernleşmesi & $\begin{array}{c}\text { Tarımsal Üretimin } \\
\text { Küreselleşmesi, Finansallaşması } \\
\text { ve Liberalleşmesi }\end{array}$ \\
\hline $\begin{array}{l}\text { Tarımsal } \\
\text { Üretim Yapısı }\end{array}$ & Aile Çiftliği & $\begin{array}{c}\text { Geniş Ölçekli Çiftlikler ve Gıda } \\
\text { Şirketleri }\end{array}$ & Büyük Ölçekli Şirketler \\
\hline $\begin{array}{l}\text { Tarımsal } \\
\text { Üretim Biçimi }\end{array}$ & Monokültür & Monokültür & $\begin{array}{l}\text { Makinizasyon, Otomasyon ve } \\
\text { Bilimsel Teknoloji }\end{array}$ \\
\hline $\begin{array}{l}\text { İhracat- İthalat } \\
\text { Yönü }\end{array}$ & Avrupa'ya Buğday ve Et İhracatı & $\begin{array}{c}\text { ABD’den Üçüncü Dünya } \\
\text { Ülkelerine Tarımsal Ürün Fazlası } \\
\text { İhracatı }\end{array}$ & İthalat \\
\hline Çöküş Nedeni & $\begin{array}{l}\text { 1. Tarımda emek kıtlığ } \\
\text { 2. Metalaştırılmış } \\
\text { tarlalar/çiftlikler } \\
\text { 3. Geniş arazili monokültürler } \\
\text { üzerinde etkinlik ölçümleri } \\
\text { 4. Buğday ve biftek üzerinde } \\
\text { küreselleşme ve } \\
\text { demokratikleşme }\end{array}$ & $\begin{array}{l}\text { 1. Gıda kıtlığı } \\
\text { 2. Petrol şokları } \\
\text { 3. Uluslararası kuruluşlar ve } \\
\text { politikalar }\end{array}$ & --- \\
\hline
\end{tabular}

Kaynak: Friedmann, 2005 [3] ve Friedmann, 2009 [4]'dan yararlanılarak hazırlanmıştır.

Birinci ve İkinci Gıda Rejimleri, öncü devletler tarafından yıkılan mevcut politikaların ardından gerçekleşmiştir. Gıda rejimlerinin en önemli özelliği değişsen güç dengeleri olmuştur. Ayrıca temel itici güçlerde yaşanan değişiklikler de gıda rejimlerindeki önemli unsurlardan biridir. Söz konusu bu temel itici güçler, gıda rejim dönemlerine göre çeşitlilik göstermekte ve Tablo-1'de yer almaktadır. Birinci ve İkinci Gıda Rejimlerinin kamu maliyesine etkileri daha ulusal düzeyde gerçekleşmiştir.

Üçüncü Gıda Rejiminin gerçekleşip gerçekleşmediği konusunda ise, tam bir netlik yoktur. Üçüncü bir rejimin gerçekleşip gerçekleşmediğini anlamak konusunda ilk iki rejime göre daha spesifik bir bakış açısı izlenmelidir. Çünkü yıllar itibariyle pek çok alanda farklılaşmalar yaşanmaktadır. Geçmişe kıyasla günümüzdeki olanaklar ve sınırlılıklar değişmiştir. Bu çerçevede Üçüncü Gıda Rejimi için egemen konumunda olan bir ülkeden ziyade birliklerden, şirketlerden söz edilebilir. Ancak söz konusu şirketler zinciri, her an yeni bir birleşmeye olasılık verecek türden bir güçtür. Gıda üretimi açısından fiyat 
belirleme gücü, firmaları kontrol etme gücü, finansal destek gücü ve üretim ya da üretimi teşvik gücünü elinde bulunduran şirket ya da şirketler topluluğu ilk iki gıda rejiminden farklı bir egemenlik rolü üstlenmektedir. Tam anlamıyla egemenliği karşılayıp karşılamadığı konusunda sinılllıklar bulunsa da gıda sektörünü yönlendirmesi ve sektörün yol haritasını etkilemesinin yanı sıra temel üreticileri baskılayan bir gücün olduğu açıktır. Bu da Üçüncü Gıda Rejiminin varlığını gösterebilir.

Üçüncü Gıda Rejimi ile İkinci Gıda Rejimi arasında yakın bir sınır olması acaba ikinci rejimin devamı mı sorusunu mutlaka akıllara getirmektedir. Aslında net bir ayrımı yapmak güçtür. Ancak ikinci rejimden farklı olarak üçüncü rejimin içinde bulunduğu dönem itibariyle finansallaşma hareketleri daha hızlı gelişmektedir. Kitlesel üretim ve gıda ihtiyacının küresel ölçekte karşılanmasının yanı sıra tarım ürünleri üzerinden geliştirilen portföyler oluşturulmaktadır. Geleneksel ticaret ilişkilerinin aksine spot ve forward piyasalar ile türev piyasalar geliştirilmektedir. Bu da gıda sektörüne yönelik olarak farklı bir üretim ve tüketim biçimlerinin ortaya çıkmasına yol açmaktadır. Üçüncü Gıda Rejiminde ise ilk iki rejimden farklı olarak gelişen uluslararası ticaret ile kamu maliyesine etkisi uluslararası düzeyde olmaktadir.

Gıda rejimlerindeki gelişmeler ve evrelerindeki değişimler ile gıda üretimi ve sonucunda da genel olarak tarımsal üretimlerde ortaya çıkan farklılaşmalar sonucunda kimi piyasalarda gıda üretiminin finansallaşması ortaya çıkmaktadır. Bu bağlamda çalışmanın izleyen başlığında tarımsal üretimde şeker piyasasında şeker pancarının rolü ve gıda rejiminin tarımsal üretimindeki etkisinin en net izleneceği yasal düzenleme olan Şeker Kanunu incelenecektir.

\section{Tarımsal Üretimde Șeker Pancarının Rolü ve Türkiye'de Șeker Kanununun İncelenmesi}

Bir ülkenin üretken kapasitesinde çeşitli sektörlerin payı vardır. Her ülkenin mevcut koşulları üretken kapasite üzerindeki paya sahip sektörleri değiştirmektedir. Geçmişte temel geçim kaynağı olan tarım sektörü aynı zamanda ülkelerin üretim kapasiteleri içinde de büyük bir paya sahip iken günümüzde bu payını sanayi sektörüne özellikle hizmetler sektörüne bırakmaktadır.

Tarım sektörü ve tarımsal üretime yönelik olarak bir tanım yapmak gerekir ise, 15 Nisan 2006'da kabul edilen 5488 Sayılı Tarım Kanunu referans olarak gösterilebilir. Kanunun üçüncü maddesinin (1) fikrasında tarımın, (j) fikrasında da tarımsal üretimin tanımı yer almaktadır. Buna göre tarım, "doğal kaynakları uygun girdilerle birlikte kullanarak yapılan her türlü üretim, yetiștirme, işleme ve pazarlama faaliyetleri" iken tarımsal üretim, "toprak, su ve biyolojik kaynaklar ile birlikte tarmsal girdiler kullanılarak yapılan bitkisel, hayvansal, su ürünleri, mikroorganizma ve enerji üretimi” olarak ifade edilmektedir.

Tarımsal üretim birçok açıdan ele alınabilir. Örneğin; yurtiçinde insanların ve hayvanların beslenme ihtiyacının giderilmesi ile hayvansal üretimin devamlılı̆̆ının korunabilmesi ve sürdürülebilmesi için gerekli ürünlerin üretimi, sanayi sektörüne girdi temini, yurtdışına ihraç edilecek ürünlerin değerlendirilmesi ve üretimi, tarımsal üretimin bir ülke ekonomisindeki ağırlığına bağlı olarak planlanacaktır. Tarımsal üretim, temel fizyolojik ihtiyaçların karşılanması açısından insan ve hayvan beslenmesinde önemli bir yere sahiptir. Ayrıca tarımsal üretim sanayiye girdi temini sağladığından hem yerli üretimde hem de dış ticarete konu olan ürünlerin üretiminde oldukça avantaj sağlamaktadır. 


\subsection{Tarımsal Üretimde Şeker Pancarı Üretiminin Payı}

Bilindiği üzere Türkiye jeopolitik konumu itibariyle oldukça verimli topraklara ve su kaynaklarına sahiptir. Ayrıca kıtaları birbirine bağlayan bir ülke konumunda olması da yüzyıllardır bu önemini korumasına katkı sağlamaktadır. Geçmişten günümüze bakıldığında Türkiye'nin bir tarım ülkesi olduğu ve bu niteliği taşıdığı açıktır. Ancak uygulamaya konulan ve/veya uygulanması planlanan politikalar tarım sektörü açısından üretimi etkilemektedir. Yıllarca tarımın GSYH içindeki payının oldukça yüksek seviyelerde olduğu bilinen bir gerçektir. Zamanla politika değişiklikleri yapıldıkça tarım sektörünün GSYH içindeki payı azalmaya başlamıştır. Bu da tarım sektöründe çalışanları doğrudan etkilemektedir.

Grafik-1’de 1923-2016 yılları arasındaki Türkiye’de tarımın GSYH içindeki payının onar yıllık ortalamalarına yer verilmektedir. 1923-2006 yılları arasındaki veriler tarım sektörünün GSMH içindeki payını göstermekte iken 2007-2016 yılları arasındaki veriler tarım, ormancılık ve balıkçılık sektörleri toplamının GSYH içindeki payını göstermektedir. Buna göre Cumhuriyetin ilk yıllarında tarım sektörünün GSYH içindeki payı yaklaşık olarak GSYH'nin yarısına yakındır. Tarihsel olarak incelendiğinde; 1923-1929 yılları arasında ulusal sermaye düzeyi zayıf, sanayi sektörü kesimi gelişmemiş ve tarımsal alanların coğrafi koşullarına bağlı olarak tarımsal üretime yatkınlık söz konusudur [5]. Dolayısıyla 1923-1930 yılları arasında tarım sektörünün GSMH içindeki payı yüksektir.

Grafik 1. Tarım Sektörünün Milli Gelir İçindeki Payı

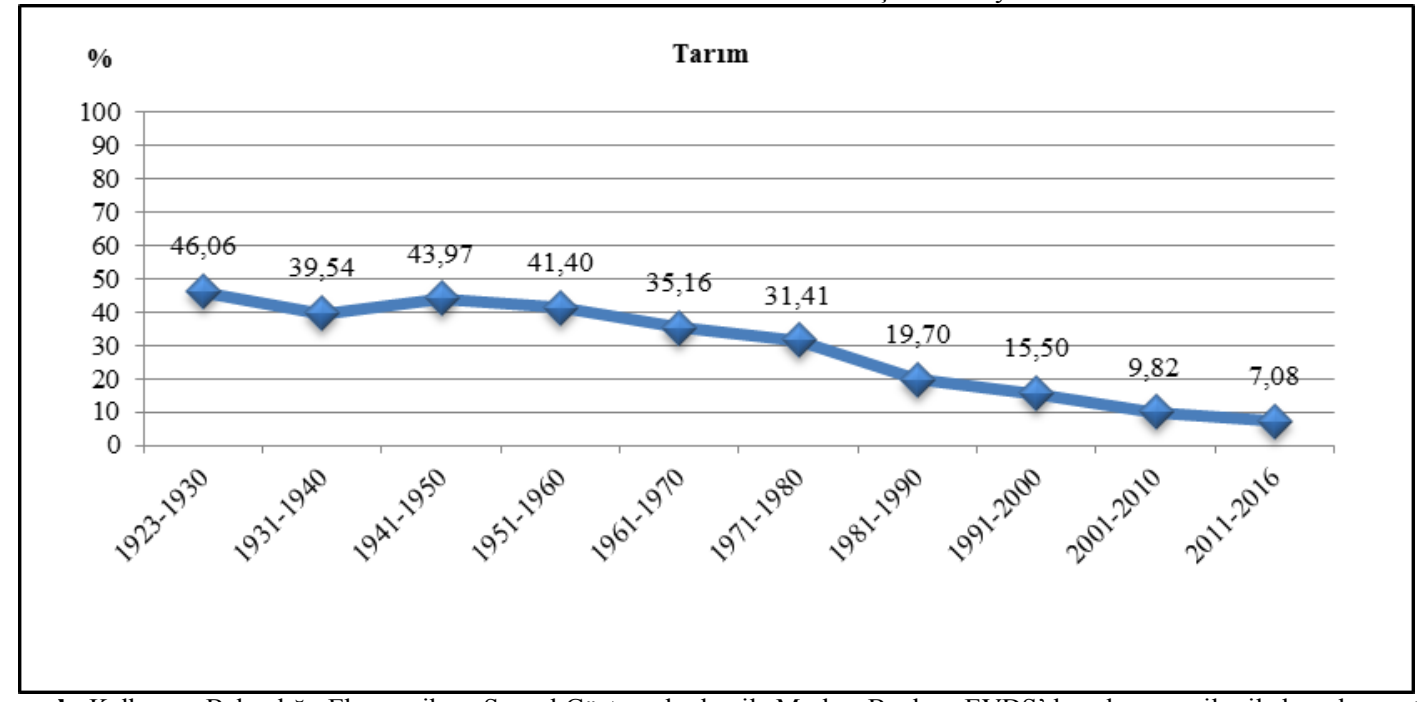

Kaynak: Kalkınma Bakanlığı, Ekonomik ve Sosyal Göstergelerden ile Merkez Bankası EVDS'den alınan veriler ile hazırlanmıştır.

Türkiye ekonomisinde planlama anlayışının yerleşmeye başlaması ile birlikte kamu politikaları da şekillenmeye başlamıştır. Söz konusu kalkınma hedefleri arasında tarım sektörü ile ilgili olanlar da vardır. Örneğin; 1933-1938 yıllarını kapsayan Birinci Beş Yıllık Sanayi Planı’nda, Türkiye’de hammaddesi olmasına rağmen tüketime yönelik olarak üretilmeyip ithal edilen ürünlerin yurtiçinde üretiminin gerçekleştirilmesi hedefi yer almış hatta bu hedef doğrultusunda Türkiye Şeker Fabrikaları kurulmuştur [6]. Bir diğer ifadeyle; Birinci Beş Yıllık Sanayi Planı’nda, ithal ikameci sanayi politikası hedefi yer almaktadır. 1931-1940 yılları arasında tarımın GSMH içindeki payının yüksekliği benimsenen politikaları yansitmaktadir. 
1960-1980 dönemi Türkiye ekonomisi tarihinde "Kalkınma Dönemi" olarak adlandırılmaktadır. Birinci Beş Yıllık Kalkınma Planı ile başlayan süreçte, 15 yıllık bir orta vadede belirlenen misyon ve vizyon çerçevesinde stratejiler hazırlanmıştır. Stratejide belirlenen planın, hedeflere ulaşabilmesi içinde beşer yıllık olarak kalkınma planları hazırlanmış ve her yıl bu planlar gözden geçirilerek revize edilmiştir. Bu çerçevede 1963-1967 ve 1968-1972 yıllarını kapsayan Birinci ve İkinci Beş Yıllık Kalkınma Planlarının amaçları arasında tarım sektörünün hacimce küçültülmesi hedefleri yer almaktadır. Birinci Beş Y1llık Kalkınma Planında tarım sektörü ve sanayi sektörünün birbirine denk olacak şekilde gelişmesi ve uzun vadede sanayiye dayalı büyüme hedefi yer almaktadır [7]. İkinci Beş Yıllık Kalkınma Planında ise; tarım sektörünün GSMH içindeki payının azaltılması hedefi yer almaktadır [8]. İzleyen kalkınma planlarında da tarımın GSMH içindeki payının giderek azaltılarak sanayi sektörüne yönelmesi temel hedefler arasında olduğundan Grafik-1 incelendiğinde 1951-1960 döneminden 2011-2016 dönemine kadar tarım sektörünün payı azaldığı görülmektedir.

Grafik-2'de 1924-2014 yılları arasındaki tarım, sanayi ve hizmetler sektörü ile GSYH'nin onar yıllık ortalama büyüme hızlarına yer verilmektedir. 1930'lara kadar tarım sektörünün diğer sektörlere oranla büyüme hızı oldukça yüksek olup 1960'lara kadar nispeten önemini korumuştur. Ancak 1960’lardan 2014'e doğru gelindiğinde tarım sektörünün büyüme hızı düşmüştür.

Grafik 2. Sektörel Büyüme Hızları

\begin{tabular}{|c|c|c|c|c|c|c|c|c|c|c|}
\hline \multirow{2}{*}{\begin{tabular}{r|}
$\%$ \\
20 \\
18 \\
16 \\
14 \\
12 \\
10 \\
8 \\
6 \\
4 \\
2 \\
0
\end{tabular}} & \multicolumn{10}{|c|}{ Büyüme Hızları } \\
\hline & $\begin{array}{l}1924- \\
1930 \\
\end{array}$ & $\begin{array}{c}1931- \\
1940\end{array}$ & $\begin{array}{l}1941- \\
1950\end{array}$ & $\begin{array}{c}1951- \\
1960 \\
\end{array}$ & $\begin{array}{l}1961- \\
1970\end{array}$ & $\begin{array}{c}1971- \\
1980 \\
\end{array}$ & $\begin{array}{l}1981- \\
1990\end{array}$ & $\begin{array}{l}1991- \\
2000\end{array}$ & $\begin{array}{l}2001- \\
2010\end{array}$ & $\begin{array}{c}2011- \\
2016\end{array}$ \\
\hline$\square$ TARIM & 13,09 & 6,28 & 3,18 & 5,72 & 1,91 & 1,58 & 1,22 & 1,70 & 1,37 & 2,02 \\
\hline$\square$ SANAYİ & 8,70 & 9,38 & 1,65 & 8,31 & 9,39 & 5,76 & 7,74 & 4,47 & 4,38 & 4,15 \\
\hline$\square$ HIZZMETLER & 8,16 & 4,35 & 2,49 & 6,58 & 6,60 & 4,98 & 5,75 & 4,22 & 4,79 & 4,52 \\
\hline घGSYH & 9,63 & 5,25 & 2,20 & 6,44 & 5,42 & 4,13 & 5,25 & 3,77 & 4,00 & 4,10 \\
\hline
\end{tabular}

Kaynak: Kalkınma Bakanlığı, Ekonomik ve Sosyal Göstergelerden alınan veriler ile hazırlanmıștır.

Tarımsal üretime konu olan bitkilerden biri olan şeker pancarı hem şeker elde edilmesinde hem de hayvan beslenmesinde kullanılmaktadır. Dünya şeker ihtiyacının karşılanmasında şeker pancarı yaklaşık \% 30'luk paya sahip olup bu ihtiyacın \% 70'lik kısmı da şeker kamışından sağlanmaktadır [9]. Dünya şeker ihtiyacının yaklaşık \% 70'inin şeker kamışından sağlanmasına rağmen şeker pancarındaki şeker oranı, şeker kamışındaki orana kıyasla daha fazladır [10].

Hayvan beslenmesinde girdi olarak kullanılabilen şeker pancarı hayvancılık sektörü açısından girdi maliyetlerini azaltabilecek bir bitki olma niteliği taşımaktadır. Örneğin; şeker pancarı fabrikalarda işlenerek ihracata konu olan mayanın temel hammaddesi oluşturan melasın üretimine katkı sağlamaktadır [11]. Böylece şeker pancarının beslenme ve hayvancılık sektöründe yem girdisi olarak kullanılmasının dışında sanayide de girdi olarak işlev görmesi söz konusudur. Ayrıca melas hayvancılık sektöründe hayvanların beslenmesinde kullanılabilecek en ucuz kaba yemlerden biridir [11]. 
Dünya şeker üretiminin önemli bir yüzdesinin şeker pancarı yerine şeker kamışından sağlanmasının nedenleri ise aşağıdaki şekilde sıralanabilir [10].

- Şeker kamışının ekiminin kolay olması,

- Daha geniş alanlarda ekilebilmesi,

- Veriminin yüksek olmasıdır.

Grafik-3’te 1991-2015 yılları arasındaki onar yıllık ortalama ekilen alan (dekar), hasat edilen alan (dekar), üretim (ton) ve verim (kg/da) verileri yer almaktadır. 1991'den 2015'e kadar şeker pancarının ekilen alanı azaldıkça dekar başına $\mathrm{kg}$ verimin arttığı görülmektedir. Küresel piyasalarda şekerin ton fiyatı yurtiçindeki üretim değerinden daha düşük olduğundan ithalat cazip konuma gelmekte dolayısıyla yurtiçinde şeker stoku artmaktadır [9]. Bu çerçevede belirlenen kamu politikaları ile şeker stoklarını azaltmak adına Türkiye'de kanuni düzenlemeler yapılmıştır. Bu düzenlemeler doğrultusunda, Şeker Kurulu kurularak stok ve üretim değerlerinin yeniden düzenlenmesi amaçlanmıştır [9].

Grafik 3. Şeker Pancarı Üretim Değerleri

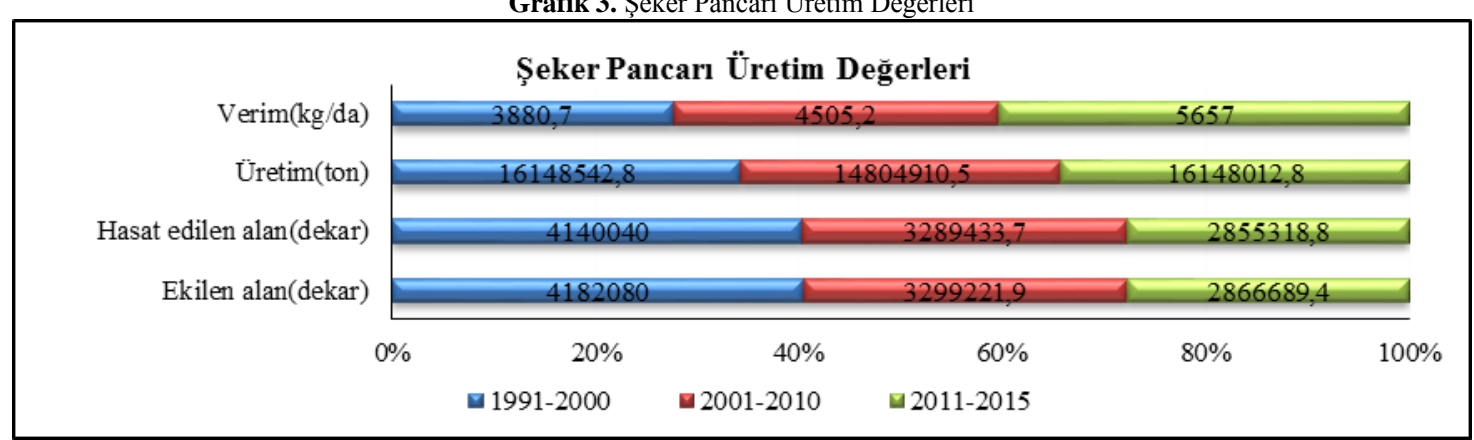

Kaynak: TUIKK, İstatistik ve Göstergelerden alınan veriler ile hazırlanmıştır.

Tablo 2. Pazarlama Yılları İtibariyle Pancar Şekeri Verileri

\begin{tabular}{|c|c|c|c|c|}
\hline Pazarlama Yılı* & $\begin{array}{l}\text { Toplam Üretim } \\
\text { (Bin Ton) }\end{array}$ & Yurtiçi Satışlar & $\begin{array}{l}\text { Yurtdıșı Satışlar } \\
\text { (C Şekeri) (Bin ton) }\end{array}$ & $\begin{array}{c}\text { Ortalama Satış Fiyatı } \\
\text { (TL/Kg) }\end{array}$ \\
\hline $2002 / 2003$ & 2.157 & 1.636 & 259 & 1,26 \\
\hline $2003 / 2004$ & 1.762 & 1.618 & 364 & 1,43 \\
\hline $2004 / 2005$ & 1.940 & 1.700 & 178 & 1,56 \\
\hline $2005 / 2006$ & 2.070 & 1.713 & 256 & 1,45 \\
\hline $2006 / 2007$ & 1.845 & 1.901 & 217 & 1,51 \\
\hline $2007 / 2008$ & 1.708 & 1.684 & 178 & 1,62 \\
\hline $2008 / 2009$ & 2.152 & 1.828 & 185 & 1,72 \\
\hline $2009 / 2010$ & 2.531 & 2.158 & 241 & 1,78 \\
\hline $2010 / 2011$ & 2.262 & 1.867 & 283 & 1,79 \\
\hline 2011/2012 & 2.270 & 2.151 & 290 & 1,94 \\
\hline $2012 / 2013$ & 2.129 & 1.918 & 339 & 2,11 \\
\hline $2013 / 2014$ & 2.390 & 2.083 & 319 & 2,33 \\
\hline 2014/2015 & 2.058 & 2.019 & 192 & 2,52 \\
\hline
\end{tabular}

* Pazarlama yılı, 1 Eylül - 31 Ağustos tarihleri arasıdır.

Kaynak: http://www.sekerkurumu.gov.tr/istatistikler/urun-verileri

Tablo-2'de pazarlama yılları itibariyle 2002-2015 dönemindeki pancar şekeri verileri yer almaktadır. Buna göre toplam üretim değerleri genel olarak artmakla birlikte birbirini izleyen dönemlerde 
azalma yönünde olduğu da görülmektedir. Tabloda yurtiçi satışlar ve yurtdışı satışların ilgili dönemlerde sürekli olarak artmasına karşın toplam üretimde zaman zaman azalmalar görülmektedir. Bunun en önemli nedenlerinden biri, şeker piyasasına yönelik düzenlenen kamu politikaları çerçevesinde şeker pancarı üretimi üzerinde uygulanan kotalar yer almaktadır.

Tablo 3' te 2002 ve 2015 pazarlama yılları itibariyle nişasta bazlı şeker verileri yer almaktadır. İhraç amaçlı dâhil toplam üretim yıllar itibariyle genel olarak artma eğiliminde olmakla beraber kimi yıllarda da azalmalar görülmektedir. Bu dalgalanmanın sebebi de nişasta bazlı şekere de uygulanan kotalardır.

Tablo 3. Pazarlama Yılları İtibariyle Nișasta Bazlı Șeker Verileri

\begin{tabular}{|c|c|c|c|c|}
\hline $\begin{array}{c}\text { Pazarlama } \\
\text { Yılı }\end{array}$ & $\begin{array}{l}\text { İhraç Amaçlı Dâhil } \\
\text { Toplam Üretim* (bin ton) }\end{array}$ & $\begin{array}{c}\text { Yurtiçi Satışlar } \\
\text { (A Kotası) (bin kota) }\end{array}$ & $\begin{array}{c}\text { Yurtdışı Satışlar } \\
\text { (C Şekeri**) }^{* *} \text { (bin ton) }\end{array}$ & $\begin{array}{c}\text { Ortama Satıș } \\
\text { Fiyatı (TL/Kg) }\end{array}$ \\
\hline $2002 / 2003$ & 394 & 353 & 33 & 0,78 \\
\hline $2003 / 2004$ & 366 & 347 & 19 & 0,91 \\
\hline $2004 / 2005$ & 433 & 360 & 61 & 0,97 \\
\hline $2005 / 2006$ & 415 & 350 & 72 & 0,93 \\
\hline $2006 / 2007$ & 440 & 350 & 88 & 0,94 \\
\hline $2007 / 2008$ & 411 & 316 & 99 & 1,03 \\
\hline $2008 / 2009$ & 418 & 333 & 83 & 1,15 \\
\hline $2009 / 2010$ & 515 & 406 & 112 & 1,17 \\
\hline $2010 / 2011$ & 516 & 367 & 150 & 1,26 \\
\hline 2011/2012 & 483 & 330 & 151 & 1,37 \\
\hline $2012 / 2013$ & 506 & 337 & 165 & 1,47 \\
\hline $2013 / 2014$ & 499 & 305 & 195 & 1,57 \\
\hline $2014 / 2015$ & 547 & 325 & 217 & 1,74 \\
\hline
\end{tabular}

* Kota tahsis edilen şirketler

** C şekeri: A ve B kotaları dışında üretilen ve yurt içinde pazarlanamayan şeker ile işlenmek üzere ihraç kaydıyla temin edilen ham ve beyaz şekeri ifade etmektedir.

Kaynak: http://www.sekerkurumu.gov.tr/istatistikler/urun-verileri

\subsection{Türkiye'de Şeker Kanunu}

Türkiye, Haziran 1998'de IMF ile Yakın İzleme Anlaşmasını ve Aralık 1999'da 17. Stand-By Anlaşmasını imzalamıştır. Ayrıca Türkiye 1990'lı yılların getirdiği kriz ortamından çıkabilmek için çareyi enflasyonu düşürecek politikalar içeren bir istikrar programı hazırlamıştır. 2000-2002 yılları arasını kapsayan Enflasyonla Mücadele Programı bir takım reform kararlarını içermektedir. Bu çerçevede Türkiye'nin IMF'e sunduğu niyet mektubunda uygulamayı planladığı tarım reformlarında, destekleme fiyatlarının dünya piyasası fiyatlarına uyumlu hale getirilmesi, tarımsal kredi ve girdi sübvansiyonlarının kaldırılması ve çiftçilere doğrudan gelir desteği sağlanması hedefleri yer almaktadır [12]. Söz konusu hedefler doğrultusunda tarımda doğrudan gelir desteği sistemine geçilmiştir [13]. Ancak Enflasyonla Mücadele Programı'nın uygulanması Kasım 2000 ve Şubat 2001 Krizleri ile sekteye uğramıştır.

Türkiye ekonomisinin Kasım 2000 ve Şubat 2001 'de bankacılık kesiminde yaşadığ krizden çıkabilmek ve ekonomiyi düzeltmek adına bir dizi reformun hazırlığı yapılmış ve uygulamasına başlanmıştır. 2002 Güçlü Ekonomiye Geçiş Programı ile yeniden bir istikrar programı hazırlanmıştır. Bu programda da tarım ile ilgili reform kararları yer almaktadır. Enflasyonla Mücadele Programı'ndan farklı olarak tarım ile ilgili reformlar artırılmıştır [14]. Güçlü Ekonomiye Geçiş Programı mali sektörün yeniden 
yapılandırılması, devlette şeffaflığın artırılması ve kamu finansmanının güçlendirilmesi, ekonomide rekabetin ve etkinliğin artırılması ve sosyal dayanışmanın güçlendirilmesi yönündeki ana başlıklardan oluşmakta olup tarım ile ilgili reform kararları ise aşağıda sıralanmıştır [13]

- "Esnaf, sanatkâr, KOBİler ve tarım kesiminin krizden asgari seviyede etkilenmelerini temin etmek amacıyla Ziraat ve Halk Bankasından kullanmış oldukları kredilerin faizlerine maliyetlerin yansıtılmasını sınırlamak amacıyla bütçeye 400 trilyon lira tutarında ödenek konmuştur.

- Şeker piyasası, Şeker Kurulu tarafindan düzenlenecektir.

- Tütün mamulleri ve alkollü içkilerin fiyatlandırılması, dağıtımı, satışı ve kontrolü ile ilgili usul ve esaslar Tütün Mamulleri ve Alkollü İçkiler Piyasası Düzenleme Kurulu tarafindan düzenlenecektir.

- Tarımsal destekleme fiyatları öngörülen enflasyonu aşmayacak şekilde artırılacak ve kuruluşların finansman imkânları dikkate alınarak miktar kısıtlamasına gidilecektir.

- Düşük gelirli çiftçilerin doğrudan gelir desteği sistemi ile güçlendirilmesi için Tarım ve Köyişleri Bakanlı̆̆ınca yürütülen çiftçi kayıt projesinin tamamlanmasl gerekmektedir. Kısa dönemde, devletin destekleme alım fiyatlarının kuruluşların finansman imkânları dikkate alınarak ve hedeflenen enflasyonu aşmayacak şekilde artırılması öngörülmektedir ”.

Şeker üretimi ile ilgili olarak alınan reform kararları çerçevesinde 18 Nisan 2001'de Şeker Kanununda düzenlenen şeker pancarında taban fiyat uygulaması kaldırılmıştır [15]. Şeker pancarındaki taban fiyat uygulamasının kaldırılmasının gerekçesi ise, 2001 öncesinde taban fiyatların belirlenmesinde politik davranılmasının üretimde aşırılığa yol açarak optimum üretim miktarından fazla üretim yapılması olarak ifade edilmiştir [12].

\section{Bir Regülasyon Kurumu Olarak Şeker Kurulu'nun Düzenleyici Rolü}

1980'li yıllardan sonra globalleşme ile beraber devletler, ekonomide bir aktör olmaktan ziyade kural koyan ve düzenleme yapan bir role sahip olmuştur. Devletlerin sahip olduğu bu işlevlerine regülasyon denilmektedir. Devletler bu regülasyon fonksiyonunu kendi kanunlarına sahip ve tüzel kişilikleri bulunan düzenleyici ve denetleyici kuruluşları ile yerine getirmektedir [16]. Bu doğrultuda T.C. Şeker Kurumu 19 Nisan 2001 yılında yürürlüğe giren 4634 sayılı Şeker Kanunu ile kurulmuştur. Şeker Kurumu, kamu tüzel kişiliğine sahip bir kurumdur. Kuruluş amacı, Şeker Kanunu ve ilgili mevzuat hükümlerinin uygulanmasının sağlanması, uygulamanın denetlenmesi ve Kanunda belirlenen yetkiler çerçevesinde düzenlemeleri yapmak ve yetkileri kullanmaktır. Şeker Kurulu da bu kurumun karar organı olarak Şeker Kanunu kapsamındaki her türlü kararı almak ve uygulamaktan sorumludur. Şeker Kurulu, Şeker Kurumu'nun karar organı olmasından dolayı kurumla benzer karakteristik özelliklere sahiptir. Bu bağlamda, iyi kurumlar, üç temel karakteristiği bünyelerinde barındırmalıdır. Söz konusu bu karakteristik özellikler aşağıda sıralanmıştır [17]:

- Birincisi, toplumun geniş bir bölümü için mülkiyet haklarının uygulanması, böylece bireylerin yatırım ve ekonomik hayata katılım için çok çeşitli teşviklere sahip olması; 
- İkincisi, elitler, politikacılar ve diğer güçlü grupların eylemlerinin kısıtlanması, böylece bu insanlar diğerlerinin gelirlerini ve yatırımlarına el koyamaz ya da son derece dengesiz bir oyun alanı oluşturamazlar;

- Üçüncüsü ise, toplumun geniş kesimleri için firsat eşitliği sağlanması, böylece bireyler, özellikle beşeri sermayeye yatırım yapabilir ve üretken ekonomik faaliyetlere katılabilirler.

Şeker Kanunu, uluslararası kuruluşlarca Türkiye tarafından hazırlanan niyet mektuplarına konu olmuş ve regülatör kurumların kontrolüne tarımsal faaliyetlerde önemli bir yere sahip olan şeker üretiminin düzenlenmesini yönlendirmiştir. Kurum ve kuruluşlar, devlet tarafından ilgili kanun ve mevzuat çerçevesinde belirli sınırlılıklarda devlet yetkisine haiz ya da devlet kontrolünde faaliyet göstermektedirler. Her ne kadar bu kurum ve kuruluşların özerk yapıda olması gerekse de yöneticilerinin ve yönetim organlarının kamu otoritesince belirlenmesi özerklik tartışmalarını beraberinde getirmektedir. Günümüzde devlete yüklenen işlevlerin sınırlandırılması söz konusu olsa da gerektiğinde devlet müdahalelerine ve desteklerine ihtiyaç duyulmakta ve bu noktada da regülatör kurumlar ortaya çıkmaktadır. Bu bağlamda devlet yanında düzenleyici kurumlara uygulamada yer verilmesi kamu sektörünün özel sektör benzeri bir yönetim mekanizmasına kavuşmasına yol açmaktadır. Bu durumun sunulan hizmet ya da üretilen malın tam kamusal, yarı kamusal ya da özel mal ve hizmet olmasına yönelik olarak olumlu yanları olabileceği gibi olumsuzlukları da bulunabilmektedir. Söz konusu bu regülasyonlardan biri de Şeker Kurulu tarafından tahsis edilen kotalardır.

Tablo 4. Şeker Kurulunca Tahsis Edilen Kotalar

\begin{tabular}{lccc}
\hline & A Kotası $^{* *}$ & B Kotası $^{* * *}$ & Toplam \\
Pancar Şekeri & 2.385 & 119,25 & $2.504,25$ \\
Nişasta Bazlı Şeker & 265 & - & 265 \\
Ülke Toplam Kotası & 2.650 & 119,25 & $2.769,25$ \\
\hline
\end{tabular}

** Yurt içi talebe göre üretilen ve pazarlama yılı içinde ülke genelinde iç pazara verilebilen şeker miktarını ifade etmektedir. Nişasta kökenli şekerler için belirlenecek toplam A kotası, Ülke Toplam A Kotasının \%10’unu geçemez. Bakanlar Kurulu bu oranı, Kurumun görüşünü alarak \%50'sine kadar artırmaya, \%50'sine kadar eksiltmeye yetkilidir.

*** Ülke toplam A kotasının belli bir oranına tekabül eden ve pazarlama yılı içinde ülke genelinde güvenlik payı için bulundurulmak üzere üretilen sakaroz kökenli depolanabilir nitelikte olan şeker miktarını ifade etmektedir.

* Şeker Kanunu gereği B Kotası tahsis edilmemektedir.

Kaynak: http://www.sekerkurumu.gov.tr/kotalar/seker-kurulunca-tahsis-edilen-kotalar

Tablo 4'te Şeker Kurulunca tahsis edilen 2016-2017 pazarlama yılına ait kotalar yer almaktadır. Pancar Şekerine uygulanan A Kotası, nişasta bazlı şekere uygulanan kotadan yaklaşık on kat fazladır bunun sebebi de çalışmanın ana konusunu oluşturan regülasyondur.

Türkiye'de 2001'de uygulamaya konulan ve tarım politikalarına yön veren Tarım Reformu Uygulama Projesi Dünya Bankası'nın desteği ile birlikte ilerlemiştir [18]. 19 Nisan 2001'de yürürlüğe giren Şeker Kanunu'nda nişasta esaslı şekerlere \% 10 kota hakkı verilerek söz konusu kotanın Bakanlar Kurulu tarafindan \% 50 oranında artırılması yetkisi yer almaktadır.

Bakanlar Kurulu da kanun ile kendisine tanınan yetki çerçevesinde kotayı artırıcı yönde davranarak Şeker Kurumu ve Şeker Kurulu tarafından kontrol edilen ABD'den genetiği değiştirilmiş mısır ithalatı ile nişasta esaslı şeker üretiminin artmasına ve buna karşlık şeker pancarı üretiminin azalmasına yol açmıştır [19]. 
Böylece mısırdan sağlanan ve bir anlamda şeker pancarının ikamesi olabilecek nişasta esaslı şekerlerin üretimi de kanundan etkilenmiştir [20]. Dolayısıyla kota uygulaması nişasta esaslı şekerlerin üretimindeki mısır üretimini olumsuz etkileyebilecek iken şeker pancarından sağlanan şeker üretimini daraltarak misır üretimini destekleyecektir [20].

Tablo 5. Pancar Şekeri Şirketlerine Tahsis Edilen Kotalar

2016/2017 Pazarlama Yılı Pancar Şekeri Kotaları (Ton)

\begin{tabular}{lcc} 
Pancar Şekeri Üreten Şirketler & A Kotası & B Kotası \\
Türkiye Şeker Fabrikaları A.Ş. & 1.361 .700 & 68.090 \\
Adapazarı Şeker Fabrikası A.Ş. & 50.000 & 2.500 \\
Amasya Şeker Fabrikası A.Ş. & 63.100 & 3.150 \\
Kayseri Şeker Fabrikası A.Ş. & 328.800 & 16.440 \\
Keskinkılıç Gıda San. ve Tic. A.Ş. & 107.000 & 5.350 \\
Konya Şeker San. Ve Tic. A.Ş. & 435.500 & 21.780 \\
Kütahya Şeker Fabrikası A.Ş. & 38.900 & 1.940 \\
Toplam & $\mathbf{2 . 3 8 5 . 0 0 0}$ & $\mathbf{1 1 9 . 2 5 0}$ \\
\hline Kaynak: http://www.sekerkurumu.gov.tr/kotalar/pancar-sekeri-sirketlerine-tahsis-edilen-kotalar
\end{tabular}

Şeker Kanunu ile şekerin satış fiyatının şeker işleticilerince kararlaştırılması uygulamasına geçilmesi nedeniyle şeker üreticilerinin fayda-maliyet oranı azalarak oluşacak şeker ihtiyacı ithalat yolu ile kapatılmaya çalışılmaktadır ancak Türkiye'nin mısıra dayalı nişasta esaslı şeker ithalatı yaparken pek çok Avrupa ülkesi şeker pancarı üretimine devam etmektedir [21].

Tablo 5 ve Tablo 6'da pancar şekeri şirketlerine ve nişasta bazlı şeker şirketlerine tahsis edilen kotalar şirketler özelinde miktar olarak ifade edilmiştir. Türkiye'de şeker piyasasında 7 pancar şeker şirketi ve 5 nişasta bazlı şeker şirketi olmak üzere 12 şirket faaliyet göstermektedir. Nişasta bazlı şeker ile pancar şekeri piyasada birbirlerinin rakibi ve alternatifi konumunda oldukları için nişasta bazlı şeker daha ucuz ve kullanımı daha kolay olduğundan daha çok tercih edilmekte ve bu da pancar şekeri şirketlerini rekabette olumsuz etkilemektedir. Ayrıca nişasta bazlı şeker üreten şirketlere daha çok üretim kotası verilmesi pancar üretimini olumsuz etkilemektedir.

Tablo 6. Nişasta Bazlı Şeker Şirketlerine Tahsis Edilen Kotalar

2016/2017 Pazarlama Yııı Nişasta Bazlı Şeker Kotaları (Ton)

$\begin{array}{lc}\text { Nişasta Bazıı Şeker Üreten Şirketler } & \text { A Kotası } \\ \text { Amylum Nişasta Sanayi ve Ticaret A.Ş. } & 82.385 \\ \text { Cargıll Tarım ve Gıda Sanayi ve Ticaret A.Ş. } & 116.181 \\ \text { Tat Nişastas İnşaat Sanayi ve Ticaret A.Ş. } & 17.077 \\ \text { Sunar Mısır Ent. Tes. Sanayi ve Ticaret A.Ş. } & 11.708 \\ \text { PNS Pendik Nişastası Sanayi A.Ş. } & 37.649 \\ \text { Toplam } & 265.000\end{array}$

Kaynak: http://www.sekerkurumu.gov.tr/kotalar/nisasta-bazli-seker-sirketlerine-tahsis-edilen-kotalar

2001'de uygulanacak reform kararları arasında Tütün ve Şeker Kanunu'nun yer alma nedeni kamu yönetimini disipline etme ve gelir sağlama gerekçesidir [22]. Şeker Kanunu ile aynı zamanda Şeker Kurumu ve Şeker Kurulu'nun kurulmasına yetki verilmiştir. Bu çerçevede Şeker Kurumu'nun öncelikli görevi yurtiçi şeker üretiminde arz ve talep dengesini sağlamaktır. Bunun yanı sıra diğer görevleri ise; 
düzenleyici ve denetleyici kurum kimliği ile ülke ve sektör yararlarını ön planda tutacak politika ve stratejiler geliştirmek, uygulanmasını sağlamak, uygulamayı izlemek ve denetlemek üzere sektördeki şirketlerin şeker üretim ve arzına yönelik faaliyetlerini yönlendirmektir [23].

Tarım sektörüne ve tarımsal üretime yönelik düzenlemeler sadece ulusal düzeyde kalmamaktadır ki; ulusal düzenlemelerin en büyük talep edenleri ve destekleyenleri uluslararası organizasyonlardır. Bu çerçevede tarımsal üretime yönelik uluslararası kuruluşların da çalışmaları bulunmaktadır. Bunlardan biri, Dünya Ticaret Örgütü tarafından gerçekleștirilen Doha Kalkınma Gündemi Tarım Müzakereleridir. Dünya Ticaret Örgütü Tarım Anlaşması'nın 20. maddesi gereğince liberalizasyonu artırma hedefi nedeniyle müzakerelerin devamına karar verilerek 2000'de Dünya Ticaret Örgütü İleri Tarım Müzakereleri başlamış ve 2001'de Doha Kalkınma Gündemi kapsamına alınmıştır [24]. Avrupa Birliği ile uyum süreci kapsamında ortak tarım politikası uygulanması yönünde bazı reform kararları alınmıştır. Bunlar genel olarak 2004'te Tarım Çerçeve Kanunu'na dayalı olarak çıkarılan Tarım Stratejisi ile doğrudan gelir desteğinin sınırlarının belirlenmesi, girdi desteği, alternatif ürün desteği, hayvancılık ve yem bitkileri desteği, tarım sigortası desteği olarak sayılabilir [12].

\section{Sonuç}

Türkiye'de Şeker Kanunu'nun hazırlanmasındaki öncü güçler dikkate alındığında gıda rejiminin üçüncü safhasında olunduğu doğrulanır nitelik taşımaktadır. Ayrıca uluslararası kuruluşların bu kanunun hazırlanmasındaki etkileri ve rolleri kurumların gücünü ortaya koymaktadır.

Eğer düzgün işleyen kurumların varlığı söz konusu olur ise, güçlü mevzuat sistemi ve devlet koruması altında mevcut politikalar ve planlanan politikalar amacına ulaşabilecektir. Ancak tüm politikaların hazırlanma süreci ve uygulanmasında ulusal sınırların yerine küresel entegrasyon süreçlerinin ağırlık taşıması yurtiçi pazarın korunmasını güçleştirerek dışsal konjonktüre bağımlı olunmasını böylece yurtiçi pazarın kırılgan bir yapı taşımasına neden olacaktır.

Şeker Kurumunun karar organı olarak yer alan Şeker Kurulu ise devletin, maliye politikalarının yanı sıra kanuni ve kurumsal önlemlerle de piyasaları düzenleyebileceğinin ve bu bağlamda da bir regülasyon kurumu olarak var olduğu ve şeker üretiminde piyasada koyduğu kotalar ile regülatör görevi gerçekleştirdiği görülmektedir. Ancak pancar şekerine uygulanan kotların nişasta bazlı şekere göre daha fazla olması sonucunda şeker pancarı üretim alanlarının daralmasına sebep olmaktadır. Bu durumun mali etkilerinin yanı sıra sosyo-kültürel etkileri de söz konusu olmaktadır. Bu bağlamda Yeni Şeker Kanunu Tasarısı'nın düzenlenerek kanun halini almasında yurtiçi pazarın rekabet gücünü artıracak hükümlerin yer alması, dışa bağımlılığının azaltılması, yerli üretimin desteklenmesi ve üretim koşullarının da küresel pazarlara uygunluğunun sağlanması yönünde politika hedeflerinin dikkate alınması yerinde olacaktır.

\section{Kaynaklar}

[1] McMichael P., "A food regime genealogy” The Journal of Peasant Studies, 36, 1, 139-169, 2009a

[2] McMichael P., "A food regime analysis of the world food crisis" Agriculture and Human Values, 26, 4, 281-295, 2009b 
[3] Friedmann H., "Research In Rural Sociology and Development: From colonialism to green capitalism: Social movements and emergence of food regimes” Edited by Marsden T., Emerald Group Publishing Limited, UK, 227-264, 2005

[4] Friedmann H., "Feeding the empire: The pathologies of globalized agriculture” Socialist Register, 41, 124-143, 2009

[5] Boratav K., “Türkiye İktisat Tarihi: 1908-2007” 14. Bask1, Imge Kitabevi, Ankara, 2010

[6] Çelebi E., “Atatürk'ün ekonomik reformları ve Türkiye ekonomisine etkileri: 1923-2002” Doğuş Üniversitesi Dergisi, 3, 1, 17-50, 2002

[7] Devlet Planlama Teşkilatı., “Kalkınma Planı (1963-1967)” Ankara, 1963

[8] Devlet Planlama Teşkilatı., “Kalkınma Planı (1968-1972)” Ankara, 1968

[9] Kolsarıı Ö., “Endüstri Bitkileri: Tarla bitkileri” Ankara Üniversitesi Ziraat Fakültesi Yayınları, 305-456, Ankara, 2011

[10] Er C., Uranbey S., "Nişasta ve Şeker Bitkileri” Ankara Üniversitesi Ziraat Fakültesi Yayını, 1504, Ankara, 1998

[11] Günel E., Çalışkan M.E., Kuşman N., Tuğrul K. M., Yılmaz A., Dede Ö., Öztürk M., "Nişasta ve şeker bitkileri üretimi” Ankara Türkiye Ziraat Mühendisliği VI. Teknik Kongresi, 2005

[12] Öztürk F., “Türkiye Ekonomisi: Tarım kesimi: Türkiye’de tarımsal yapı ve tarımsal destekleme politikalarının tarihsel gelişim süreci” Editör Arslan G. E., Gazi Üniversitesi Illetişim Fakültesi Basımevi, Ankara, 61-92, 2008

[13] TCMB, “Türkiye’nin Güçlü Ekonomiye Geçiş Programı” Ankara, 2001

[14] Şahin H., “Türkiye Ekonomisi” 10. Bask1, Ezgi Kitabevi Yayınları, Bursa, 2009

[15] Şahin B., "Toplumsal Olaylar Yönetimi: Toplumsal olayların kamu politikaları üzerindeki etkisi” Editör Kara H.B., Efil Yayınevi, Ankara, 368-378, 2014

[16] İliman T., Tekeli R., “Türkiye’de düzenleyici ve denetleyici kuruluşlar: İdari para cezalarının hukuksal zeminlerinin değerlendirilmesi” Adnan Menderes Üniversitesi Sosyal Bilimler Enstitüsü Dergisi, 3, 1, 23-36, 2016

[17] Acemoğlu D., “Root causes” Finance \& Development, 40, 2, 27-43, 2003

[18] Demirdöğen A., Olhan E., "Türkiye ve Rusya tarımsal ticaretinin politika değişimi açısından değerlendirilmesi” Tarım Ekonomisi Dergisi, 20, 2, 101-111, 2014

[19] Günaydın G., “Türkiye tarım politikalarında yapısal uyum: 2000'li yıllar” Mülkiye Dergisi, 33, 262, 175-222, 2009

[20] Taşdan K., Emeksiz F., “Türkiye'de mısır üretim, tüketim ve dış ticareti”, Ç.Ü.Z.F. Dergisi, 18, 3, 97-104, 2003

[21] Öztornacı B., Veziroğlu P., “Küreselleşme ve Türkiye'de kırsal yoksulluk”, 10. Ulusal Tarım Ekonomisi Kongresi, 290-298, 2012

[22] Suiçmez B. R., “Tütün Sektöründe Değişim: Imf - Dünya Bankası Anlaşmaları ve Tütün Yasası” 2002 http://www.antimai.org/tme/imftutun.htm 
[23] Karakaş M., “Devletin düzenleyici rolü ve Türkiye'de bağımsız idari otoriteler” Maliye Dergisi, 154, 99-120, 2008

[24] Dünya Ticaret Örgütü. (2016) http://www.tarim.gov.tr 